\title{
An Unsuccessful Attempt to Isolate Human Immunodeficiency Virus (HIV) from Patients with Primary Immunodeficiency Diseases
}

\author{
Tadashi Kanoh, Tatsuharu Ohno, Shinji Harada* and \\ Hiroshi Fujit \\ The First Division, Department of Internal Medicine, \\ Faculty of Medicine, *Institute for Virus Research, Kyoto \\ University, Kyoto 606 and $\dagger$ the Third Division, Department \\ of Internal Medicine, the First Kyoto Red Cross Hospital, \\ Kyoto 605
}

Kanoh, T., Ohno, T., Harada, S. and Fuji, H. An Unsuccessful Attempt to Isolate Human Immunodeficiency Virus (HIV) from Patients with Primary Immunodeficiency Diseases. Tohoku J. exp. Med., 1987, 152 (4), 391-395 Isolation of the human immunodeficiency virus (HIV) was performed in 5 seronegative patients with primary immunodeficiency diseases (IDDs) who had no or little ability to produce antibodies and received a large amount of intravenous gammaglobulin (IVG) for a long period. In this study cultured cells were considered to be infected if the following 2 criteria were met: (1) They produced reverse transcriptase (RT) activity in the supernatant fluid and (2) expressed viral antigens. Under experimental conditions, virus was demonstrated by both RT activity and viral antigen expression detectable by immunofluorescence technique in lymphocyte cultures from 2 seropositive patients with acquired immunodeficiency syndrome-related complex who were examined as controls. There was no evidence of HIV infection in cultures of lymphocytes from all of the 5 patients with primary IDDs and from 2 healthy subjects. The above patients did not show the extremely low numbers of target $\mathrm{T} 4+$ cells, which make isolation of the virus in lymphocytes difficult. The present results suggest that current methods of IVG preparation either remove or inactivate HIV. ——acquired immunodeficiency syndrome (AIDS); human immunodeficiency virus (HIV); intravenous gammaglobulin ; primary immunodeficiency diseases

Administration of blood and blood products (Anderson et al. 1986; Melief and Goudsmit 1986) has been known as a route of transmission of the human immunodeficiency virus (HIV, formerly LAV/HTLV-III). Although the antibody against HIV has been detected in intramuscular and intravenous gammaglobulin (IVG) preparations (Gocke et al. 1986; Wood et al. 1986), the viral transmission has not been reported so far. Webster et al. (1986), however, reported the isolation of retroviruses related HIV from peripheral bood mononuclear

Received May 18, 1987 ; accepted for publication July 13, 1987. 
cells of 2 patients with common variable immunodeficiency (CVID) who were being treated with IVG. Iatrogenic infection from IVG could not be ruled out. IVG is the mainstay of treatment in some types of immunodeficiency diseases (IDDs). Patients with primary IDDs are repeatedly administered with IVG. They may be more susceptible to viral infection associated with parenteral blood products, but they are unable to cause a normal antibody response to the viruses. Thus, to investigate whether IVG may be safely administered in patients with primary IDDs, follow-up study of these patients should be done by detection of the virus rather than anti-HIV antibody (Kanoh et al. 1986). The purpose of this study is to evaluate the risk of transmission of HIV via administration of IVG in immunocompromised adult patients treated with IVG.

\section{Materials and Methods}

Patients. Five adult patients with primary IDDs receiving IVG were studied. All of 4 commercially available IVG preparations administered were from an American source. None of the patients belonged to known risk group for the acquired immunodeficiency syndrome (AIDS), nor had any clinical evidence of the disorder. Immunologic diagnoses included CVID in 3 patients, immunodeficiency with hyper-IgM in 1, and selective IgG2 deficiency in 1. All of the patients had been receiving almost monthly IVG therapy for at least 3 years. The cumulative dosage of IVG was more than $350 \mathrm{~g}$. After informed consent was obtained, 2 healthy subjects and 2 patients with AIDS-related complex (ARC) were also tested as controls for virus isolation.

Sample collection. The fresh sera were obtained from 30 to 45 days after the last administration of IVG. Heparinized venous blood obtained from study participants was separated by centrifugation on a Ficoll-Paque (Pharmacia, Uppsala, Sweden) gradient.

Determination of anti-HIV. Antibody to HIV was determined by enzyme-linked immunosorbent assay (ELISA) ("Virgo", Electro-Nucleonics, Inc., Columbia, MD, USA). Cut-off value for ELISA was 0.100 .

Virus isolation and serologic procedures. The virus-isolaton techniques we used have been described elsewhere (Feorino et al. 1985; Harada et al. 1985). Briefly, lymphocytes $\left(2 \times 10^{6} / \mathrm{ml}\right)$ from study participants were co-cultured with 3-day-old normal human lymphocytes $\left(2 \times 10^{6} / \mathrm{ml}\right)$ stimulated with $1 \%$ (v/v) PHA-M in RPMI- 1640 medium containing rIL-2 $(200 \mathrm{U} / \mathrm{ml})$. Normal human lymphocytes from the same donor were added every 3 to 4 days. The cultures were monitored for virus replication by immunofluorescence (IF) technique and viral reverse transcriptase (RT) assays which were performed at 2 and 3 weeks after cocultivation. Staining of HIV-specific antigens was performed by the indirect IF technique (Harada et al. 1985) using $1: 1000$ diluted serum from a patient with seropositive hemophilia (IF titer to HIV , $1: 4096$ ) and FITC-labelled anti-human IgG (Dakopatts A/S, Copenhagen, Denmark). Culture fluids were assayed for RT activity according to the method previously reported (Harada et al. 1985). In this experiment, values of less than $2000 \mathrm{cpm}$ in RT activity assay were accepted as a negative result. Cultured cells were considered to be infected if the following 2 criteria were met: (1) They produced RT activity in the supernatant fluid and (2) expresed viral antigens in the cytoplasm.

\section{RESULTS}

Only serum samples from 2 patients with ARC contained antibodies to HIV as detected by ELISA. The virus isolation was confirmed in these patients on the basis of RT activity and viral antigen expression (Table 1, Fig. 1). All of the 5 
TABLE 1. Reverse transcriptase and virus antigen expression

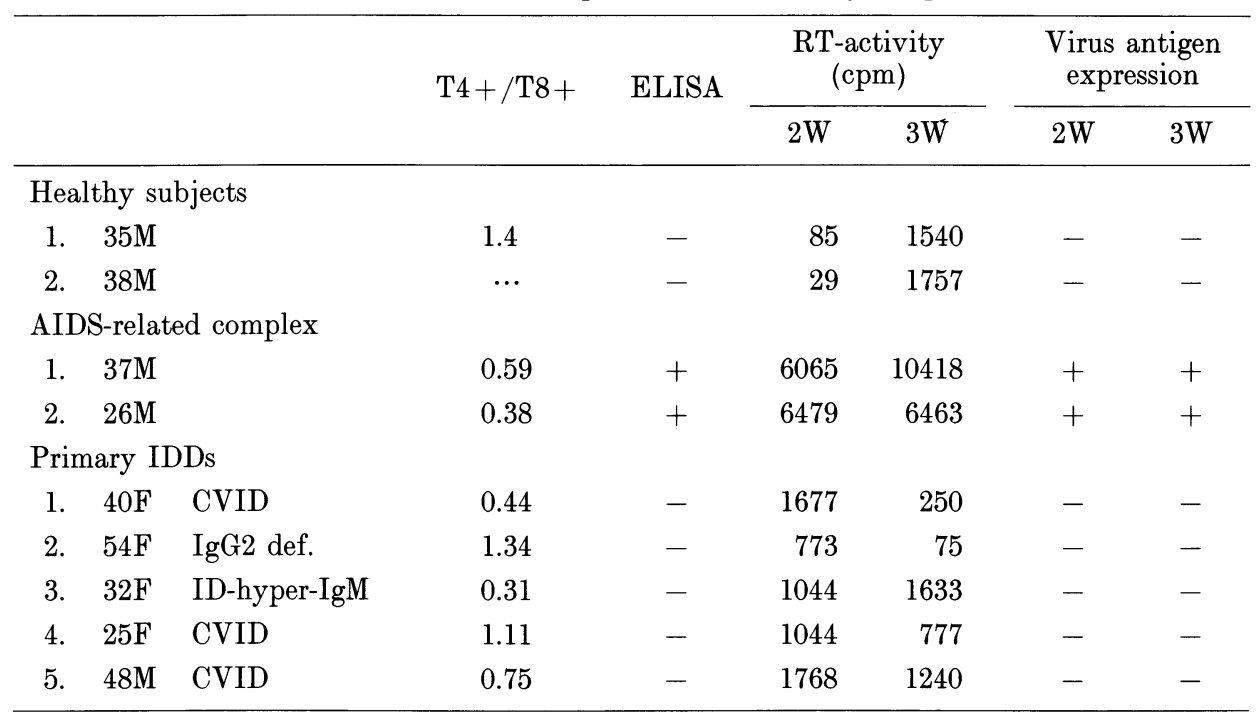

ID-hyper-IgM, immunodeficiency with hyper-IgM.

patients with primary IDDs did not have the extremely low numbers of target $\mathrm{T} 4+$ cells, which may make virus isolation difficult. There was no evidence of HIV infection in cultures of lymphocytes from the patients with primary IDDs

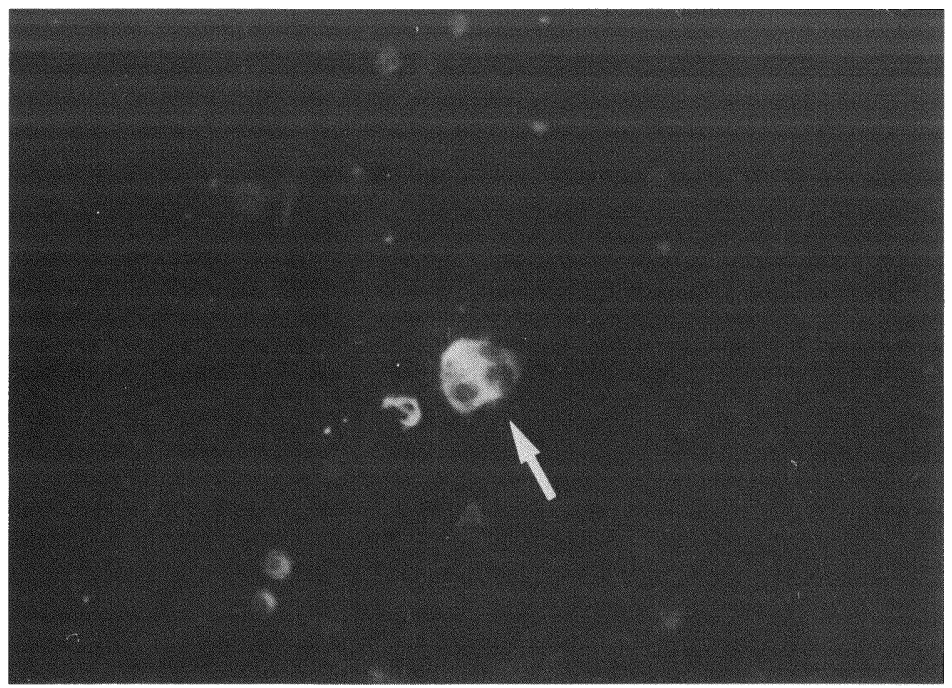

Fig. 1. Viral antigen expression in ARC (Case 1). HIV released into supernatant fluids was transmitted to PHA-stimulated normal peripheral blood lymphocytes in which HIV-specific antigen was detected by IF technique. Note a typical giant cell (arrow) with peripheral localization of nuclei arising by cell fusion which is usually observed at the time of virus replication. 
and from 2 healthy subjects.

\section{Discussion}

As a rule, cultures for HIV are positive for seropositive individuals and are negative for seronegative ones (Ward et al. 1987). However, a minor population of seronegative individuals can harbor HIV. Seronegative but virus-positive state may occur in the several conditions. There is an interval between exposure to virus and antibody production (Wall et al. 1987). In fact, an infectious but anti-HIV negative donor has infected recipients before seroconversion (Centers for Disease Control 1986). It is possible that in some immunodeficient individuals antibody to HIV may never develop in association with viral infection (Bernstein and Rubinstein 1986). On the other hand, HIV may have an especially high attack rate in immunocompromised hosts (Scott et al. 1984 ; Anderson et al. 1986). It is also conceivable that antibody to HIV is produced but is complexed with viral antigens and therefore is undetectable by the current method (Salahuddin et al. 1984). In order to confirm whether HIV infection may occur in these instances, virus isolation or HIV antigen determination should be done (Wall et al. 1987). The sufficient number of target $\mathrm{T} 4+$ cells is a prerequisite to HIV isolation (Bowen et al. 1985). All of the 5 patients with primary IDDs we examined had the number of $\mathrm{T} 4+$ cells ample for virus isolation. There was no clinical, serologic or virologic evidence of HIV infection in 5 patients with primary IDDs who had been treated with IVG. In addition, as far as we know, HIV transmission via administration of IVG has not been reported in patients with primary IDDs who are repeatedly administered with IVG for long periods and show a high susceptibility to viral infections (Morell et al. 1986). These observations suggest that the current preparation methods of IVG either exclude or inactivate HIV (Tedder et al. 1985; Wood et al. 1986). Since virus isolation by currently available techniques may be influenced by unknown factors, a further extensive study about this problem should be made to obtain definite conclusions.

\section{Acknowledgments}

We thank Dr. Norimune Funakoshi, Miki Jiyugaoka Hospital, and Dr. Shigeo Nomura, Hyogo Prefectural Amagasaki Hospital, whose co-operation made this work possible.

\section{References}

1) Anderson, K.C., Gorgone, B.C., Marlink, R.G., Ferriani, R., Essex, M.E., Benz, P.M. \& Groopman, J.E. (1986) Transfusion-acquired human immunodeficiency virus infection among immunocompromised persons. Ann. intern. Med., 105, 519-527.

2) Bernstein, L.J. \& Rubinstein, A. (1986) Acquired immunodeficiency syndrome in infants and children. Progr. Allergy, 37, 194-206.

3) Bowen, D.L., Lane, H.C. \& Fauci, A.S. (1985) Immunopathogenesis of the acquired immunodeficiency syndrome. Ann. intern. Med., 103, 704-709. 
4) Centers for Disease Control (1986) Transfusion-associated human T-lymphotropic virus type III/lymphadenopathy-associated virus infection from a seronegative donorColorado. MMWR, 35, 380-391.

5) Feorino, P.M., Jaffe, H.W., Palmer, E., Peterman, T.A., Francis, D.P., Kalyanaraman, V.S., Weinstein, R.A., Stoneburner, R.L., Alexander, W.J., Raevsky, C., Getchell, J.P., Warfield, D., Haverkos, H.W., Kilbourne, B.W., Nicholson, J.K.A. \& Curran, J.W. (1985) Transfusion-associated acquired immunodeficiency syndrome. Evidence for persistent infection in blood donors. New Engl. J. Med., 312, 1293-1296.

6) Gocke, D.J., Raska, K., Jr., Pollack, W. \& Schwartzer, T. (1986) HTLV-III antibody in commercial immunoglobulin. Lancet, 1, 37-38.

7) Harada, S., Koyanagi, Y. \& Yamamoto, N. (1985) Infection of human Tlymphotropic virus type-I (HTLV-I)-bearing MT-4 cells with HTLV-III (AIDS virus) : Chronological studies of early events. Virology, 146, 272-281.

8) Kanoh, T., Ohno, T., Funakoshi, N., Fujii, H. \& Okada, T. (1986) LAV/HTLV-III antibodies in patients treated with intravenous gammaglobulins. Tohoku $\mathrm{J}$. exp. Med., 150, 361-362.

9) Melief, C.J.M. \& Goudsmit, J. (1986) Transmission of lymphotropic retroviruses (HTLV-I and LAV/HTLV-III) by blood transfusion and blood products. Vox Sang., 50, 1-11.

10) Morell, A., Barandun, S. \& Locher, G. (1986) HTLV-III seroconversion in a homosexual patient with common variable immunodeficiency. New Engl. J. Med., 315, 456457.

11) Salahuddin, S.Z., Groopman, J.E., Markham, P.D., Sarngadharan, M.G., Redfield., R. R., McLane, M.F., Essex, M., Sliski, A. \& Gallo, R.C. (1984) HTLV-III in symptomfree seronegative persons. Lancet, 2, 1418-1420.

12) Scott, G.B., Buck, B.E., Leterman, J.G., Bloom, F.L. \& Parks, W.P. (1984) Acquired immunodeficiency syndrome in infants. New Engl. J. Med., 310, 76-81.

13) Tedder, R.S., Uttley, A. \& Cheingsong-Popov, R. (1985) Safety of immunoglobulin preparation containing anti-HTLV-III. Lancet, 1, 815.

14) Wall, R.A., Denning, D.W. \& Amos, A. (1987) HIV antigenaemia in acute HIV infection. Lancet, 1, 566.

15) Ward, J.W., Deppe, D.A., Samson, S., Perkins, H., Holland, P., Fernando, L., Feorino, P.M., Thompson, P., Kleinman, S. \& Allen, J.R. (1987) Risk of human immunodeficiency virus infection from blood donors who later developed the acquired immunodeficiency syndrome. Ann. intern. Med., 106, 61-62.

16) Webster, A.D.B., Dalgleish, A.G., Malkovsky, M., Beattie, R., Patterson, C., Asherson, G.L., North, M. \& Weiss, R.A. (1986) Isolation of retroviruses from two patients with "common variable" hypogammaglobulinaemia. Lancet, 1, 581-583.

17) Wood, C.C., Williams, A.E., McNamara, J.G., Annunziata, J.A., Feorino, P.M. \& Conway, C.D. (1986) Antibody against the human immunodeficiency virus in commercial intravenous gammaglobulin preparations. Ann. intern. Med., 105, 536-538. 